\title{
Chemistry and molecular biology of platinum anticancer drugs
}

\author{
Stephen J. Lippard \\ Department of Chemistry, Massachusetts Institute of Technology, Cambridge, \\ Massachusetts 02139, USA
}

\begin{abstract}
Important features of DNA structure and the reactions of platinum complexes with solvent and media components are reviewed. Within the context of this background information are presented details of the binding of the anticancer drugs cis- $\left[\mathrm{Pt}\left(\mathrm{NH}_{3}\right)_{2} \mathrm{Cl}_{2}\right]$ (cis-DDP), $\left[\mathrm{Pt}(\mathrm{en}) \mathrm{Cl}_{2}\right]$, and $\left[\mathrm{Pt}\left(\mathrm{NH}_{3}\right)_{2}(\mathrm{CBDCA})\right]$ (carboplatin), as well as the chemotherapeutically inactive isomer trans-DDP, to DNA. After hydrolysis of the chloride ligands from cis-DDP, the $\left\{\mathrm{Pt}\left(\mathrm{NH}_{3}\right)_{2}\right\}^{2+}$ moiety primarily forms a crosslink between adjacent guanosine nucleosides on the same strand of the DNA double helix. The resulting adduct has been structurally characterized on single-stranded DNA in the solid state by X-ray diffraction and on single-stranded and duplex DNA in solution by NMR spectroscopy. Platinum binds to the N7 atoms of the guanine rings, unstacks the bases, and switches the sugar pucker of the 5'-nucleotide from $\mathrm{C} 2$ '-endo to $\mathrm{C} 3^{\prime}$-endo. Molecular mechanics calculations of both single- and double-stranded DNA-platinum adducts have been carried out to model additional features of the structures. An intrastrand crosslink also forms between adjacent adenosine and guanosine nucleosides in DNA treated with cis-DDP. Studies with monoclonal antibodies demonstrate

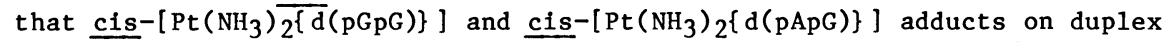
DNA are structural analogs of one another, and that carboplatin forms the same adducts as cis-DDP. The regioselectivity of cis-DDP and [ $\left.\mathrm{Pt}(\mathrm{en}) \mathrm{Cl}_{2}\right]$ binding to DNA is controlled by local sequences in which the principal $\mathrm{d}(\mathrm{pGpG})$ targets are embedded. This selectivity can be modified by addition of external intercalators, such as ethidium bromide, during the platination reaction. Similar behavior occurs for A0-Pt, a novel molecule in which dichloroethylenediamineplatinum(II) is linked by a hexamethylene chain to acridine orange. The preferred binding sites of trans-DDP on single-stranded DNA have also been mapped. This isomer forms intrastrand crosslinks between two guanosines, or an adenosine and guanosine, having one or more intervening nucleotides. Structural studies by NMR spectroscopy have been carried out on trans $-\left\{\mathrm{Pt}\left(\mathrm{NH}_{3}\right)_{2}\right\}$ adducts of $\mathrm{d}(\mathrm{GpTpG})$ (N7$G(1), N 7-G(3)), d(G p C p G)(N 7-G(1), N 7-(G(3))$, and [d(ApGpGpCpCpT) ] 2 (N7$A(1), N 7-G(3))$. Antinucleoside antibodies show clearly that trans-DDP adducts are more disruptive of the DNA double helix than those formed by cis-DDP since the intervening nucleotides in the former cannot form Watson-Crick base pairs with their complements on the unplatinated strand. A strategy for investigating the cytotoxicity, mutagenicity, and repair of intra- and interstrand crosslinks formed by cis-DDP, trans-DDP, and their analogs is presented. Specifically, construction of Ml3 DNA containing the cis-[Pt $\left.\left(\mathrm{NH}_{3}\right)_{2}\{\mathrm{~d}(\mathrm{pGpG})\}\right]$ adduct built into a unique, programmable site in the genome is described. Chemical and biological studies of such substrates should enable unambiguous information to be obtained about the viability and lethality of individual Pt-DNA adducts in vivo and, ultimate$1 \mathrm{y}$, lead to the design of better heavy metal anticancer drugs.
\end{abstract}

\section{INTRODUCTION}

\section{Brief clinical history}

The discovery of anticancer activity in mice of cis-diamminedichloroplatinum(II), cis-DDP or cisplatin, and the finding that the isomer trans-DDP is inactive were reported in the late 1960 's. ${ }^{1}$ Following extensive clinical trials, cisplatin was approved by the U. S. Food and Drug Administration in 1979. It has subsequently become a leading selling anticancer drug, being most effective against testicular, ovarian, and head and neck tumors. ${ }^{2}$ Although other cis-[Pt $\left.\left(\mathrm{NR}_{3}\right)_{2} \mathrm{X}_{2}\right]$ complexes, such as $\left[\mathrm{Pt}(\mathrm{en}) \mathrm{Cl}_{2}\right]$, exhibit anticancer activity, only one, cis$\left[\mathrm{Pt}\left(\mathrm{NH}_{3}\right)_{2}(\mathrm{CBDCA})\right]$, where CBDCA = cyclobutane-1,1-dicarboxylate, or carboplatin, has been released in the United Kingdom for the treatment of tumors, owing to its less toxic side effects compared to cisplatin. ${ }^{3}$ The failure of patients to respond to cisplatin chemotherapy is often accompanied by resistance to the drug. ${ }^{4}$ Understanding the biochemical mechanisms 
by which cis-DDP is toxic to tumor cells at doses that normal cells can withstand, by which trans-DDP is rendered ineffective at doses where cis-DDP is active, and by which cells become resistant to cis-DDP are objectives that have attracted a wide range of scientists, from inorganic chemists to cell biologists, to join forces to work in this area.<smiles>N[Pb](N)(Cl)Cl</smiles>

cisplatin<smiles>NCC[Pb](Cl)(Cl)Cl</smiles>

$\mathrm{Pt}(\mathrm{en}) \mathrm{Cl}_{2}$<smiles>N[PH3+](N)(Cl)Cl</smiles>

trons-DDP

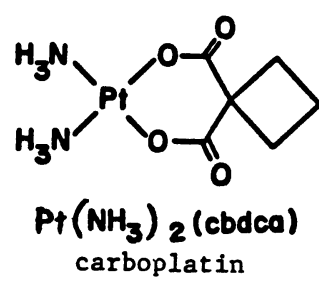

\section{DNA as the target}

Evidence pointing to DNA replication as the major function impaired by cis-DDP in the tumor cell, responsible for its cytotoxicity and anticancer activity, has been summarized elsewhere. 5 The ability of cis-DDP adducts on DNA to stop the processive action of DNA polymerase translates into inhibition of cell division and, hence, antitumor activity.

Recent studies of the inhibition of replication of viral DNA in simian virus 40 (SV40) ininfected African green monkey kidney (CV-1) cells illustrate the dramatic difference in the effects of cis- versus trans-DDP in the cell culture medium. ${ }^{6}$ As shown in Fig. $1,10 \mu \mathrm{M}$ cisDDP inhibits SV 40 DNA replication to $75 \%$ of control (no Pt present), a concentration at which trans-DDP is ineffective. At higher concentrations, however, the trans isomer also inhibits DNA synthesis in this system. The inhibition of SV40 DNA replication is a function of the amount of platinum bound per nucleotide for both isomers. 6

Once it was generally accepted that DNA is a principal target for cis-DDP in cells, responsible for its cytotoxicity, attention turned to identifying the major binding modes of platinum to this biopolymer (Fig. 2). DNA interstrand crosslinking ${ }^{7}$ and protein-DNA crosslinks ${ }^{8}$ were readily identified, owing to the relative ease of detecting reactions that covalently link macromolecules under denaturing conditions. Although suggested early, ${ }^{9}$ characterization of DNA intrastrand crosslinks was more difficult.10-12 Platinum induced intrastrand crosslinking occurs most frequently in the reactions of cis-DDP with DNA, and consequently serves as a focus for much of the following discussion.

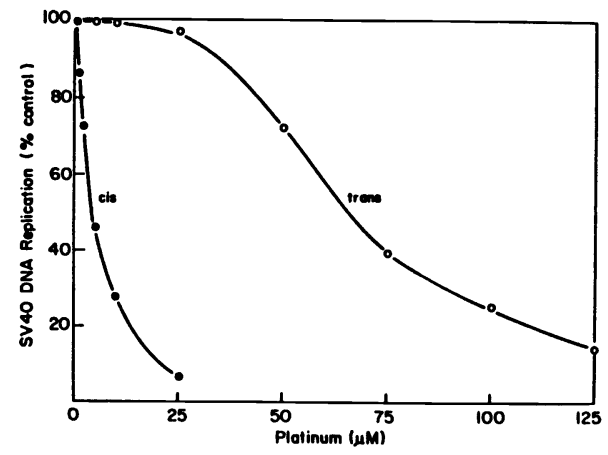

Fig. 1. SV40 DNA replication in CV-1 cells as a function of concentration of cis-DDP or trans-DDP in the medium (from ref. 6).
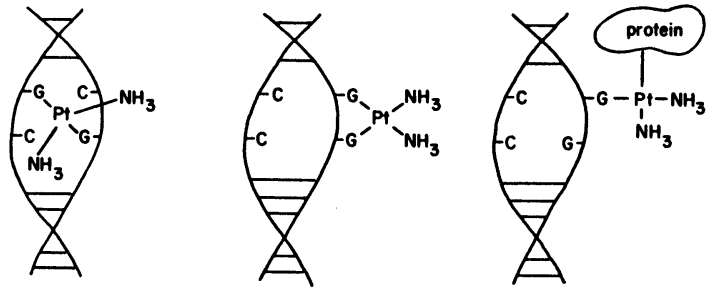

Fig. 2. Three preferred binding modes of the cis-diammineplatinum(II) fragment to DNA, the interstrand crosslink (left), intrastrand crosslink (center), and DNA-protein crosslink (right) (from ref. 13).

\section{Scope of this article}

The present article summarizes important structural details of the adducts of cisplatin with DNA. Much progress has been made since a review of this topic only two years ago.13 Moreover, in this time period, attention has also turned to understanding DNA reaction products of transDDP. For, even though the trans isomer is inactive, knowledge of its DNA binding modes is important as a means of calibrating the biological consequences of cis-DDP-DNA adducts. These new findings are also discussed here. DNA is possibly the most complex multidentate ligand studied by coordination chemists. The ability to make progress in unravelling the regio- and stereochemistry and -specificity of its platinum binding properties was greatly facilitated by joint efforts of scientists applying newly emerging methodologies from the diverse disciplines of molecular biology, cell biology, immunology and bioinorganic chemistry. This article tries to capture the spirit of such a collaborative enterprise. 


\section{PROPERTIES OF DNA}

\section{Fundamental building blocks}

DNA is a polymer composed of a deoxyribose sugar-phosphate backbone and four nucleotide bases (Fig. 3). The preferred heavy metal binding sites at neutral pH are N7 of guanine and adenine, $\mathrm{N} 3$ of cytosine, and $\mathrm{N} 1$ of adenine, rather than the exocyclic amino or keto groups or the phosphate and deoxyribose ring oxygen atoms.14 The purine $\mathrm{N7}$ atoms are the most available for coordination in double helical DNA, being exposed to solvent in the major groove of B-DNA and uninvolved in Watson-Crick hydrogen bonding.
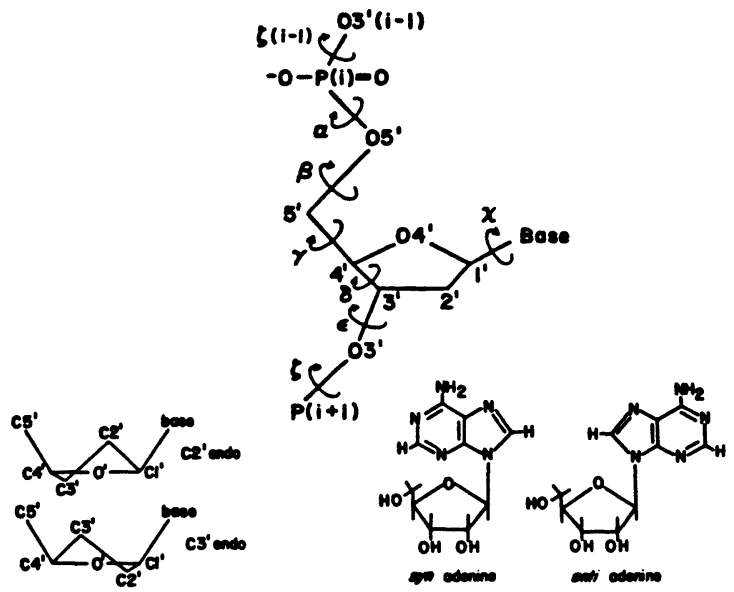

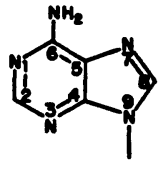

ADENOBINE

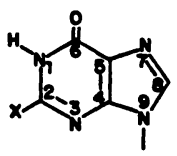

$X \cdot \mathrm{NH}_{2}$ ' CUANOSINE<smiles>[R]c1cn(C)c(=O)n([Hg])c1=O</smiles>

$R=\mathrm{CH}_{\mathbf{2}}$ ' THYMIDNE<smiles>Cn1c(=O)nc2nc(N)ccn21</smiles>

Fig. 3. Sugar-phosphate backbone of DNA exhibiting conformational angles and deoxyribose ring puckers (left). The four bases adenine (A), guanine (G), cytosine (C), and thymine

$(\mathrm{T})$ are shown with their numbering schemes (right). Adapted from ref. 14.

\section{DNA polymorphism}

The three-dimensional structure of duplex DNA is sensitive to local sequence. The classical form of DNA is the B structure, with well-defined major and minor grooves, C2'-endo deoxyribose sugar puckers, and parallel stacked base pairs running perpendicular to the helix axis.15 A, $C, D$, and left-handed $Z$ forms of DNA also exist, however (Fig. 4). These alternate forms can be stabilized by varying the salt conditions, degree of superhelical winding, and DNA sequence. The $\mathrm{Z}$ form, for example, is preferred in high salt solutions of poly $\mathrm{d}(\mathrm{GC})$. DNA polymorphism is probably even more complex, however, with sequence dependent alternate structures occurring even within a given genome. Thus, $A, B, C, D$, and $Z$ forms may only begin to approximate the geometric complexity of the double helix. The occurrence of sequence dependent local structures along DNA has recently been mapped by photoactivated chiral metal complexes, 16 by chemical probes such as diethylpyrocarbonate, 17 and by various other chemical and immunological methods. 15

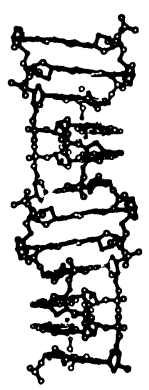

Z-DNA

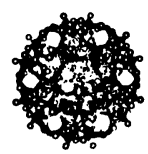

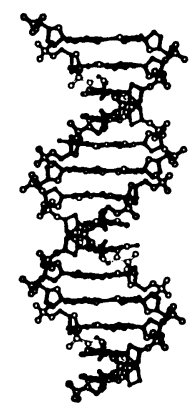

B-DNA

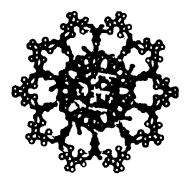

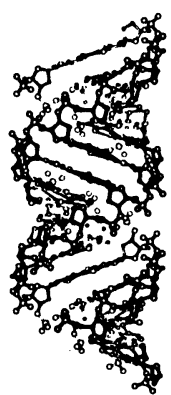

A-DNA

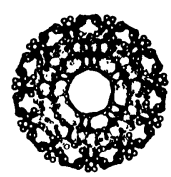

Fig. 4. Structures of $A, B$, and $Z$ polymorphs of DNA. Adapted from ref. 15. 


\section{Nucleosomes and chromatin}

In the nucleus of eucaryotic cells, DNA is compacted by being wound in a shallow, left-handed superhelix around a group of eight histone proteins to form nucleosome core particles. These core particles are further organized into a solenoidal structure called chromatin through interactions with additional histone proteins.15 Chromatin is anchored to a scaffold of proteins within the chromosomes. How might these various organizational levels affect platinum drug binding to DNA? Although the answer to this question is unknown at a detailed, chemical level, some insight is available. To become functionally active for translation or replication, the solenoid and nucleosome structure must unravel and the DNA strands separate, at least transiently. The binding of platinum complexes to such forms of DNA in vivo, as in the experiments with SV40 infected $\mathrm{CV}-1$ cells mentioned above, would thus share features with platinum bindexperiments conducted with pure DNA in vitro. Comparative studies of cis-DDP binding to DNA from the nucleosome core particle, both free and as the nucleoprotein complex, reveal little quantitative difference in the rate of formation or nature of the products obtained.18 Nevertheless, many other structural and DNA processing proteins occur in vivo that cannot be adequately modeled by in vitro platinum binding experiments, and further studies of the interaction of platinum compounds with chromatin are warranted.

\section{PLATINUM COMPLEXES AND THEIR REACTIONS WITH SOLVENTS AND MEDIA}

\section{Platinum complexes}

In addition to the four compounds depicted above, two other platinum(II) complexes have been used in conjunction with studies described here. The [Pt(dien)Cl] ${ }^{+}$cation is of ten employed in control experiments, for it can only form a single bond to DNA.19 The other molecule, A0Pt, contains the intercalator acridine orange linked by a hexamethylene tether to dichloroethylenediamineplatinum(II).20 The structures of these complexes are depicted below.
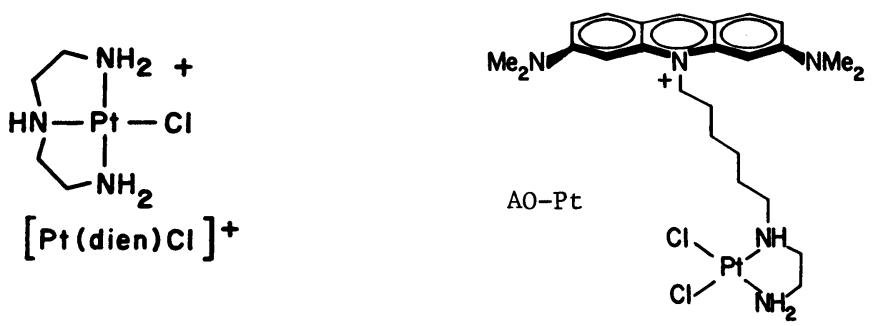

\section{Hydrolysis and media reactions}

The aqueous solution chemistry of platinum(II) complexes has been reviewed previously.21 Eq. (1) illustrates the stepwise hydrolysis reactions of both cis- and trans-DDP to form aqua species that can deprotonate at physiological pH. Although chloride ion is a better trans

\begin{tabular}{|c|c|c|c|c|}
\hline $\mathrm{PtCl}_{2}\left(\mathrm{NH}_{3}\right)_{2}$ & $\frac{-\mathrm{Cl}^{-}}{+\mathrm{Cl}^{-}}$ & $\begin{array}{c}\mathrm{Pt}\left(\mathrm{NH}_{3}\right)_{2} \mathrm{Cl}\left(\mathrm{H}_{2} \mathrm{O}\right)^{*} \\
+\mathrm{H}^{+} \| 1-\mathrm{H}^{+} \\
\mathrm{Pt}\left(\mathrm{NH}_{3}\right)_{2} \mathrm{Cl}(\mathrm{OH})\end{array}$ & $\frac{-\mathrm{Cl}^{-}}{\stackrel{+\mathrm{Cl}^{-}}{ }}$ & $\begin{array}{c}\mathrm{Pt}\left(\mathrm{NH}_{3}\right)_{2}\left(\mathrm{OH}_{2}\right)_{2}^{+2} \\
+\mathrm{H}^{+} \| 1-\mathrm{H}^{+} \\
\mathrm{Pt}\left(\mathrm{NH}_{3}\right)_{2}\left(\mathrm{OH}_{2}\right)(\mathrm{OH})^{+}\end{array}$ \\
\hline
\end{tabular}

\footnotetext{
labilizing ligand than ammonia, it is also a better leaving group. 22 The first product formed is therefore $\left[\mathrm{Pt}\left(\mathrm{NH}_{3}\right)_{2} \mathrm{Cl}\left(\mathrm{OH}_{2}\right)\right]^{+}$, rather than $\left[\mathrm{Pt}\left(\mathrm{NH}_{3}\right) \mathrm{Cl}_{2}\left(\mathrm{OH}_{2}\right)\right]$. The compounds cis- and transDDP hydrolyze according to eq. (1) with retention of stereochemistry. Subsequent reactions with DNA also occur with retention of stereochemistry.
}

The presence of chloride ion in plasma and cells modulates the reactivity of cis- and transDDP in vivo, according to eq. (1). It is generally accepted that the drug, typically administered as an intravenous injection, is activated upon crossing cellular membranes. During this process, the chloride ion concentration drops from $\sim 0.1 \mathrm{M}$ to $\sim 3 \mathrm{mM}$, producing greater quantities of the kinetically more reactive aquated complexes according to eq. (1).23 It is these hydrolyzed forms that react with DNA.

Platinum complexes also bind other components in media commonly used in cell culture experiments, with trans-DDP being more reactive, and hence more rapidly inactivated, than cis-DDP. In carrying out comparative studies with cis-DDP and trans-DDP, it is advisable, for example, to keep fetal calf serum concentrations below $5 \%$ and to avoid normal mouse serum. 24 P1atinum complexes also react with glutathione, metallothionein, and amino acids.25,26 Although millimolar concentrations of glutathione (GSH) are present in cells, depletion of GSH levels has 
little effect on the cytotoxicity of cis-DDP, [Pt(en)C12], or carboplatin, although it does potentiate the toxicity of trans-DDP. 27 Intravenous infusion of diethyldithiocarbonate 28 or thiosulfate ${ }^{29}$ reduces nephrotoxicity when administered in conjunction with cisplatin chemotherapy.

These various anecdotal cases illustrate the effects of sulfur donor ligands on the molecular biology of platinum complexes, as expected from hard-soft acid-base principles of coordination chemistry. This potential reactivity must be kept in mind when designing and interpreting mechanism of action studies of platinum anticancer drugs.

Owing to its excellent solvation properties, dimethyl sulfoxide $\left(\mathrm{Me}_{2} \mathrm{SO}\right)$ is commonly used to dissolve compounds in biological studies. Many of the earliest experiments with cisplatin employed $\mathrm{Me}_{2} \mathrm{SO}$ as solvent, 7 a practice which unfortunately has persisted.30,31 Kinetic studles reveal that $\mathrm{Me}_{2} \mathrm{SO}$ substitutes for a single chloride ligand according to eq. (2) for both

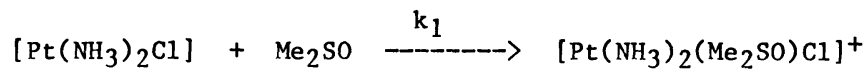

cis- and trans-DDP, a reaction that can be followed by $195 \mathrm{Pt}$ NMR spectroscopy (Fig. 5).32 At $37^{\circ} \mathrm{C}$, the half-lives of cis- and trans-DDP are 60 and $8 \mathrm{~min}$, respectively, for solvolysis. These values indicate that use of $\mathrm{Me}_{2} \mathrm{SO}$ as solvent is a more serious problem for the trans isomer. cis-DDP reacts further with $\mathrm{Me}_{2} \mathrm{SO}$ to form several products in which $\mathrm{Pt}-\mathrm{NH}_{3}$ bonds have been broken, owing to the kinetic trans effect of sulfur-bound $\mathrm{Me}_{2} \mathrm{SO}$ ligands.33 Studies of trans-DDP binding to calf thymus DNA and to the model DNA substrate $d(\mathrm{Gp}-$ $\mathrm{TpG}$ ) revealed significant differences in the rate of platinum binding and the spectrum of products obtained when the complex was dissolved in aqueous buffer versus $\mathrm{Me}_{2} \mathrm{SO}$ for on 1 y $5 \mathrm{~min}$ utes prior to dilution with aqueous media.32 These findings require that, in the interpretation of results for biological experiments employing $\mathrm{Me}_{2}-$ So as a solvent for platinum complexes, due consideration be given to the likelihood that coordination of $\mathrm{Me}_{2} \mathrm{SO}$ to platinum in the reactive species fundamentally alters the nature of products formed with DNA.

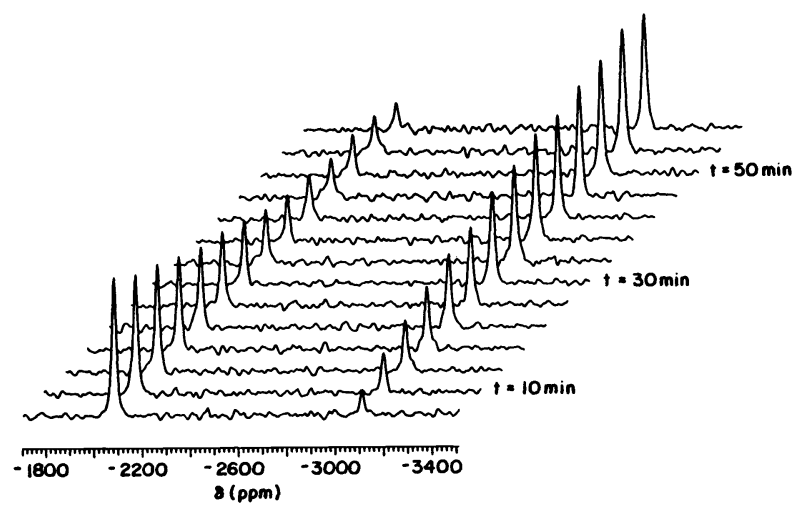

Fig. 5. Time dependent 195 PT NMR spectra of transDDP ( $\delta-2086 \mathrm{ppm}$ ) in $\mathrm{Me}_{2} \mathrm{SO}^{-\mathrm{d}_{6}}$ at $26{ }^{\circ} \mathrm{C}$, recorded every $4 \mathrm{~min}$, showing the formation of trans-[Pt$\left.\left(\mathrm{NH}_{3}\right)_{2}\left(\mathrm{Me}_{2} \mathrm{SO}\right) \mathrm{Cl}\right]^{+}(\delta-3112 \mathrm{ppm})$. See $\overline{\text { ref. }} 32$.

\section{ADDUCTS FORMED WHEN cis-DDP AND RELATED MOLECULES BIND TO DNA}

\section{Enzymatic and chromatographic mapping of adducts}

When cis-DDP binds to DNA, it promotes superhelical unwinding and shortens the double he$11 \times .19,34$ The shortening but not the unwinding can be eliminated if the intercalator ethidium bromide is present during platination. 35 Subsequent removal of ethidium by dialysis restores the DNA shortening effect. These results suggested two modes of cis-DDP binding to DNA. One mode results in short-range intrastrand crosslinks and superhelical unwinding. The second, ethidium bromide dependent, binding mode involves long-range crosslinks that are slower to form.

Enzymatic mapping studies of DNA platinated by cis-DDPl0-12,36 or $\left[\mathrm{Pt}(\mathrm{en}) \mathrm{Cl}_{2}\right]^{37}$ revealed a strong preference for binding to sequences containing two or more adjacent guanosine nucleosides. The quantitization of these and other, less common, adducts was achieved by first degrading DNA platinated in vitro ${ }^{38-40}$ or in vivo4l with a combination of nucleases and then separating and identifying the resultant fragments by chromatography and, for the in vivo study, immunochemical techniques. These studies revealed that intrastrand $\mathrm{d}(\mathrm{GpG})$ crosslinks account for $65 \%$ of the adducts formed in vitro and $35 \%$ of those formed in vivo. In addition, the in vitro results revealed that $\sim 25 \%$ of the platinum forms $d(\mathrm{ApG})$ intrastrand cross 1 inks, with long-range intrastrand and interstrand G-G crosslinks and monofunctional binding accounting for the remaining $10 \%$ of bound platinum. In vivo, the interstrand and DNA-protein crosslinks each amounted to less than $0.2 \%$ of the adducts found at bound drug-to-nucleotide (D/N) ratios of $\sim 5 \times 10^{-5} .41$ 


\section{Immunochemical studies of cis-DDP-DNA adducts}

When DNA containing bound cis-DDP is injected into animals, antibodies are raised that can be isolated and used as tools for studying platinum-DNA interactions.42-44 These antibodies are specific for cis-DDP-DNA adducts and do not recognize adducts of trans-DDP or $[\mathrm{Pt}(\mathrm{dien}) \mathrm{Cl}]^{+}$. Extensive investigations of platinated homo- and heterocopolymers such as poly $(\mathrm{dG}) \cdot \mathrm{poly}(\mathrm{dC})$, poly[d(GC)]•poly[d(GC)] and poly[d(AG)] poly[d(TC)] using these polyclonal4 4 and several monoclonal $1^{45}$ antibodies revealed the primary antigenic determinant to be the $\mathrm{cis}-\left[\mathrm{Pt}\left(\mathrm{NH}_{3}\right){ }_{2}\{\mathrm{~d}(\mathrm{GpG})\}\right]$ intrastrand crosslink, and, to a lesser extent, the intrastrand d(ApG) crosslink. DNA platinated with $\left[\mathrm{Pt}(\mathrm{en}) \mathrm{Cl}_{2}\right],\left[\mathrm{Pt}(\mathrm{dach}) \mathrm{Cl}_{2}\right]$, and $\left[\mathrm{Pt}\left(\mathrm{NH}_{3}\right)_{2}(\mathrm{cbdca})\right]$ was recognized by the antibodies, demonstrating that all three of these biologically active compounds form similar intrastrand $\mathrm{d}(\mathrm{GpG})$ and $\mathrm{d}(\mathrm{ApG})$ crosslinks. Polyclonal antibodies raised against the specific adduct cis[Pt( $\left.\mathrm{NH}_{3}\right)_{2}$ (Guo)(GMP)] also provided evidence for the formation of the cis-[Pt( $\left.\left.\mathrm{NH}_{3}\right)_{2}\{\mathrm{~d}(\mathrm{pGp} G)\}\right]$ adduct both in vivo and in vitro.41

Anti-nucleoside antibodies have also been used to probe structural aspects of the binding of cis-DDP to DNA.46 At relatively high levels of binding ( $D / N \sim 0.1$ ), cis-DDP disrupts base pairing sufficiently well to promote recognition of anti-nucleoside antibodies with anti-cytosine $>$ anti-adenosine $\sim$ anti-thymidine $\gg$ anti-guanosine. This ordering is consistent with the intrastrand $\mathrm{d}(\mathrm{GpG})$ crosslink being the major adduct. In an important control experiment, it was shown that cis-[Pt $\left.\left(\mathrm{NH}_{3}\right){ }_{2}\{\mathrm{~d}(\mathrm{GpG})\}\right]$ does not bind to the anti-guanosine antibody.

\section{DNA binding of an intercalator-linked platinum complex}

Enzymatic mapping studies of cis $-\left[\mathrm{Pt}\left(\mathrm{NH}_{3}\right)_{2} \mathrm{Cl}_{2}\right]^{47}$ and $\left[\mathrm{Pt}(\mathrm{en}) \mathrm{Cl}_{2}\right]^{37}$ binding to duplex DNA revealed that certain oligo(dG) sequences failed to bind platinum at low $\mathrm{D} / \mathrm{N}$ ratios of $\sim 0.01$. When the intercalator ethidium bromide $(\mathrm{EthBr})$ was present during platination, however, these became preferred sequences for drug binding. The most common such sequences contained the $\mathrm{d}(\mathrm{pCpGpG)}$ trinucleotide, and it was postulated that this sequence might perturb local DNA structure such as to render inaccessible guanosine $\mathrm{N} 7$ atoms, the preferred binding sites for platinum on DNA.37 Restoration of a more normal, B-DNA type local structure could occur upon addition of EthBr, activating the site for platinum binding.

The ability of an intercalator to restore platinum binding to such sequences will depend in part upon its mean residence time at the site. Thus, acridine orange $(\mathrm{A} 0)$, which dissociates from its sites of intercalation on DNA more rapidly than $\mathrm{EthBr}, 48$ fails to activate binding sites inaccessible to cis-DDP and $\left[\mathrm{Pt}(\mathrm{en}) \mathrm{Cl}_{2}\right]$ at low $\mathrm{D} / \mathrm{N}$ ratios. ${ }^{37}$ On the other hand, $\mathrm{AO}-\mathrm{Pt}$, a molecule in which the acridine orange ring is tethered to ethylenediamineplatinum(II) by a $\mathrm{fCH}_{2} \mathrm{f}_{6}$ chain, is able to bind at these positions. This molecule effectively raises the local platinum concentration near the site of intercalation such that binding to form the $d(G p G)$ crosslink can occur before the acridine moiety dissociates and the DNA can relax to its unmodified structure. Irradiation of A0-Pt-DNA adducts by visible light results in cleavage of the sugar-phosphate backbone of the biopolymer near the sites of platinum binding. 20 Thus, molecules of this kind have the interesting potential for self-mapping the regiospecificity of their DNA binding chemistry.

\section{STRUCTURAL STUDIES OF MAJOR cIS-DIAMMINEPLATINUM-DNA ADDUCTS}

\section{Dinucleotides}

Proton NMR spectroscopic studies of chromatographically purified cis-diammineplatinum(II) adducts of several ribo- and deoxyribonucleotides have been carried out. Intrastrand crosslinks between two N7 guanosine or adjacent $5^{\prime}$ adenosine and $3^{\prime}$ guanosine nucleosides were characterized for $(\mathrm{GpG}), 49,50 \mathrm{~d}(\mathrm{GpG}), 50,51 \mathrm{~d}(\mathrm{pGpG}), 50$ and $(\mathrm{ApG}) .52$ Assignment of platinum binding sites was facilitated by the fact that coordination of the heavy metal to $\mathrm{N} 7$ of guanosine lowers the $\mathrm{pK}_{\mathrm{a}}$ of the $\mathrm{Nl}$ proton by $\sim 2$ units (Fig. 6), a phenomenon readily detected by monitoring the $\mathrm{pH}$ dependence of the chemical shift of the H8 proton NMR resonance. A conformational analysis ${ }^{5}$ of cis- $\left[\mathrm{Pt}\left(\mathrm{NH}_{3}\right)_{2}\{\mathrm{~d}(\mathrm{GpG})\}\right]^{+}$revealed a switch in the conformation of the $5^{\prime}$ deoxyribose ring from $\mathrm{C} 2$ '-endo to $\mathrm{C}^{\prime}$ '-endo upon platination and anti conformations about both glycosidic linkages (Figs. 3 and 6). Similar results were obtained from NMR studies of $\mathrm{cis}-\left[\mathrm{Pt}^{\left(\mathrm{NH}_{3}\right)_{2}-}\right.$ $(\mathrm{ApG})]^{+.52}$ Coupling constants, such as $\mathrm{J}_{\mathrm{H} 1}{ }^{\prime} \mathrm{H} 2^{\prime}, 2^{\prime \prime}$, and nuclear Overhauser effects for the non-exchangeable base and sugar protons facilitate these conformational assignments.

A single crystal X-ray diffraction study of cis-[Pt $\left.\left(\mathrm{NH}_{3}\right)_{2}\{\mathrm{~d}(\mathrm{pGpG})\}\right]$ supplied several additional important geometric details of this, the major adduct of cis-DDP with DNA. 53 As illustrated in Fig. 7, coordination of cis-diammineplatinum(II) to two adjacent guanosine nucleosides at N7 positions closes a 17-membered ring. The backbone compression enforced by this intrastrand crosslink results in a $\mathrm{C}^{\prime}$-endo sugar pucker at the $5^{\prime}$ nucleoside. The two guanine base planes are completely destacked, forming a dihedral angle in the $76.2(5)-86.7(6)^{\circ}$ range for the four independent molecules in the crystal lattice. Average Pt-N bond lengths of 2.00 2.04 are in the normal range for platinum-ammine or -pyridine complexes. Hydrogen bonding occurs between the $5^{\prime}$ terminal phosphate oxygen atom and a coordinated ammine, OP $1 \mathrm{~A} \cdot \cdots \mathrm{N} 11$ in Fig. 7. One interesting aspect of the structure, revealed by examining space filling computer graphics displays, is that the exocyclic 06 atoms of the guanosine rings, oriented in a headto-head fashion on the same side of the platinum coordination plane, block access by a fifth ligand. This feature might be important in designing new heavy metal anticancer drugs. 


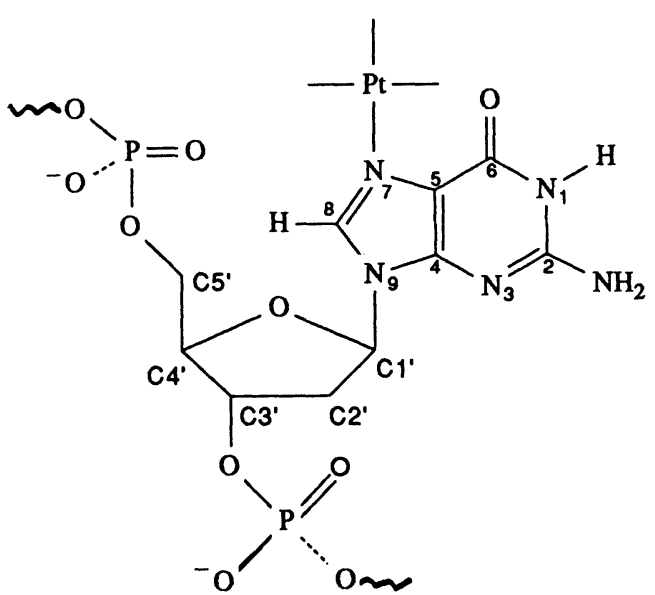

Fig. 6. Schematic of the platinated deoxyguanosine nucleoside, showing the conventional atom labelling. The base is rotated into the anti position about the glycosidic ( $\left.\mathrm{N9}-\mathrm{Cl}^{\prime}\right)$ bond.

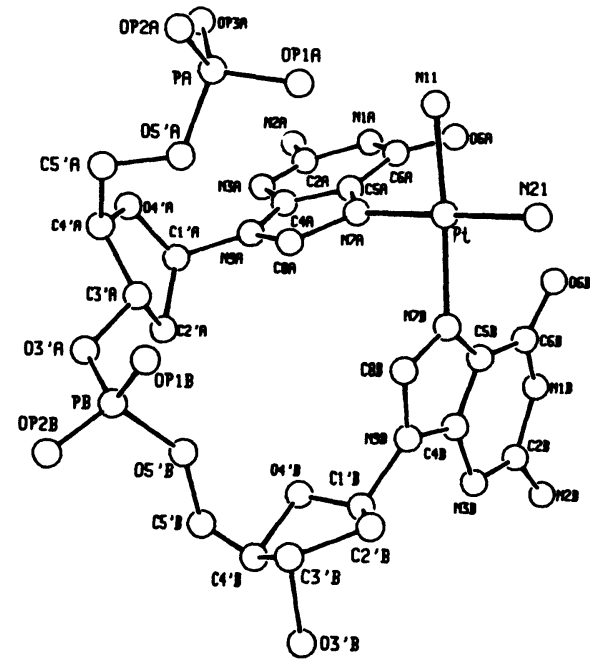

Fig. 7. Molecular structure of one of four cis- $\left[\mathrm{Pt}\left(\mathrm{NH}_{3}\right)_{2}\{\mathrm{~d}(\mathrm{pGpG})\}\right]$ molecules in the crystal structure of this adduct. 53

\section{Oligonucleotides}

Interest arose in studying the binding of cis-DDP to $d(G \mathrm{pNpG})$ fragments, where $\mathrm{N}$ is any intervening nucleoside, following a report ${ }^{54}$ that intrastrand platinum crossilinking of the two guanosine residues in such sequences is especially mutagenic in bacteria. Although platinated $d(G p G)$ and, especially, $d(A p G)$ sequences were subsequently found to be significantly more mutagenic, 55 the results of the earlier study led to several NMR investigations of tri- and oligonucleotides containing $\mathrm{cis}-\left\{\mathrm{Pt}\left(\mathrm{NH}_{3}\right)_{2}\right\} 2+$ bound to 7 of guanosine nucleosides separated by an intervening nucleotide. Specifically, cis-diammineplatinum(II) adducts of $\mathrm{d}(\mathrm{GpCpG}), 56,57$

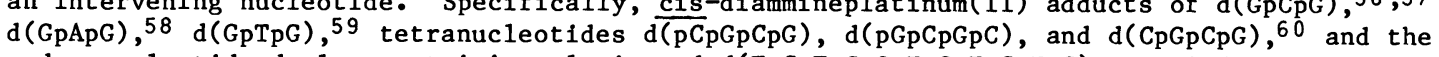
undecanucleotide duplex containing platinated $d(\mathrm{TpCpTpCpGpTpGpTpCpTpC)}$ annealed to its complementary strand, 61 have been examined. The last was especially instructive, demonstrating that platinum coordination to the two deoxyguanosine $N 7$ atoms of the d $(\mathrm{pG}$ GTpG $)$ sequence causes substantial disruption of the double helix. Switching of the deoxyribose ring sugar pucker completely over to $\mathrm{C}^{\prime}$-endo does not occur for any of these platinated $d(\mathrm{GNG}$-containing oligonucleotides.

NMR and X-ray diffraction studies of cis- $\left[\mathrm{Pt}\left(\mathrm{NH}_{3}\right)_{2}\{\mathrm{~d}(\mathrm{CpGpG})\}\right]$ have been reported.62,63 The structure of the platinum induced intrastrand $d(\mathrm{GpG})$ crosslink in this compound is very similar to that in the corresponding $\mathrm{d}(\mathrm{pGpG})$ adduct (Fig. 7).53 Numerous other NMR studies of singlestranded $60,64-68$ and duplex ${ }^{6-71}$ platinated oligonucleotides, containing from 4 to 12 nucleotides, have been reported. In general, these compounds exhibit the same geometric features found in shorter platinated oligomers, with a C3'-endo sugar pucker on the $5^{\prime}$-modified guanosine. It is significant that the $\mathrm{d}(\mathrm{GpG})-\mathrm{platinum}$ adducts in [d(GpApTpCpCpG $\left.{ }_{\mathrm{p}}^{*}{ }_{\mathrm{p}}^{*} \mathrm{C}\right) \bullet \mathrm{d}(\mathrm{GpCpCpGpG-}$

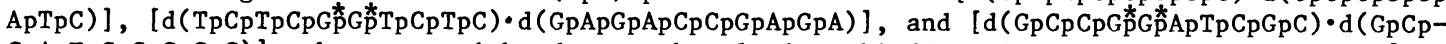
GpApTpCpCpGpGpC)], where asterisks denote the platinum binding sites, again resemble cis-[Pt$\left.\left(\mathrm{NH}_{3}\right)_{2}\{\mathrm{~d}(\mathrm{pGpG})\}\right]$ in that $\mathrm{N} 7$ coordination of adjacent nucleosides occurs with simultaneous repuckering of the $5^{\prime}$ sugar to the C3'-endo conformation. In addition, the molecules are doublestranded below $25^{\circ} \mathrm{C}$. The formation of a kink at the site of platination has been postulated.69-70 Molecular mechanics calculations support the notion that such a kinked structure might be stable,72,73 but unkinked models involving some disruption of base pairing, especial$1 \mathrm{y}$ at the $5^{\prime}$ coordinated guanosine nucleoside, are also energetically feasible.73,74 Additiona1 NMR and other biophysical studies of double-stranded oligonucleotides containing the cisdiammineplatinum(II) crosslink between adjacent guanosine nucleosides are required to discern the conditions under which linear and kinked duplex structures might exist.

\section{DNA}

Attempts to soak cis-DDP into existing crystals of $\mathrm{DNA}^{75}$ or tRNA,76,77 in order to obtain geometric information about platinum binding by $X$-ray methods, have been only partially successful. Diffusion of the complex into pre-grown crystals of the B-DNA duplex dodecamer [d(GpCpGpCpApAp-

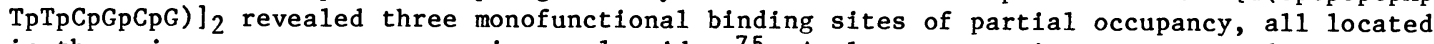
in the major groove near guanosine nucleosides. ${ }^{75}$ Analogous experiments were performed with $\mathrm{t}-\mathrm{RNA}^{\text {Phe }}, 76,77$ one of which showed drug binding near (GpG), (GpGpApG), and (ApG) sequences.77 
This latter study offered a nice rationale for why, in an (ApGpA) sequence in double-stranded nucleic acids, cis-diammineplatinum(II) will prefer to coordinate to $\mathrm{N} 7$ atoms of the ApG, rather than the GPA, site. Following its coordination to N7 of G(2), the platinum atom is $3 \AA$ from $N 7$ of $\mathrm{A}(1)$ and $\sim 5 \AA$ from $\mathrm{N} 7$ of $\mathrm{A}(3)$, hence its preference for binding to the $5^{\prime}$ nucleoside. As described above, cis- $\left[\mathrm{Pt}\left(\mathrm{NH}_{3}\right)_{2}\{\mathrm{~d}(\mathrm{ApG})\}\right]$ adducts are relatively common for DNA platinated with cis-DDP, whereas $\mathrm{d}(\mathrm{GpA})$ intrastrand crosslinks are not.

\section{trans-DDP BINDING TO OLIGONUCLEOTIDES AND DNA}

\section{Replication mapping of binding sites}

Until recently, structural details of the binding of trans-DDP were unavailable, largely owing to the disinterest in studying the chemotherapeutically inactive analog. Neglect of transDDP-DNA binding modes is unjustified, however, for they help to rule out aspects of the molecular mechanism of the cis isomer. trans-Diamminedichloroplatinum(II) hydrolyzes more rapidly and forms both DNA-protein and DNA interstrand crosslinks somewhat more efficiently than cisDDP. $6,21,78,79$ Its preferences for intrastrand crosslink formation are less regiospecific, as revealed by replication mapping studies.36 In particular, trans-DDP inhibits duplex synthesis

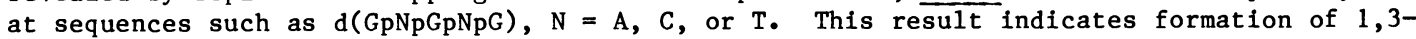
intrastrand crosslinks between $\mathrm{N} 7$ atoms of guanosine bases separated by an intervening nucleotide. Unlike the 1,2-intrastrand $d(G p G)$ crosslink, this 1,3-crosslink is stereochemically feasible for the trans $-\left\{\mathrm{Pt}\left(\mathrm{NH}_{3}\right)_{2}\right\}^{2+}$ moiety.

\section{Oligonucleotides}

The binding of trans-DDP to three oligonucleotides, single-stranded $d(G p T p G), 80 \mathrm{~d}(\mathrm{GpCpG}), 81$ and double-stranded $\left[\mathrm{d}(\mathrm{ApGpGpCpCpT)}]_{2}, 82\right.$ has been studied. In all three cases, the products are single-stranded and contain the trans-diammineplatinum(II) $d(G N G)$ or, in the case of the hexanucleotide, $d(A N G)$ 1,3-intrastrand crosslink. In the case of the $\mathrm{d}(\mathrm{GpCpC})$ and [d(ApGp-

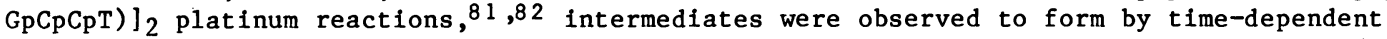
chromatographic studies and, eventually, to convert into the intrastrand crosslinked adducts. Platinum binding to $\mathrm{N} 7$ of deoxyguanosine and deoxyadenosine was established by $\mathrm{pH}$ dependent ${ }^{1} \mathrm{H}$ NMR chemical shift experiments analogous to those employed in cis-DDP-oligonucleotide investigations. A switch in deoxyribose sugar pucker from $\mathrm{C} 2$ '-endo to $\mathrm{C} 3^{\prime}$-endo upon platination was observed for the $5^{\prime}$ guanosine in $\mathrm{d}(\mathrm{GpCpG})^{81}$ and the $5^{\prime}$ adenosine in $\mathrm{d}(\mathrm{ApGpGpCpCpT})^{82}$ from the $\mathrm{H} 1^{\prime}-\mathrm{H} 2^{\prime}$ coupling constants and NOE experiments. A similar sugar pucker alteration was also reported for trans $-\left[\mathrm{Pt}\left(\mathrm{NH}_{3}\right){ }_{2}\{\mathrm{~d}(\mathrm{GpTpG})\}\right]$, but the specific nucleoside undergoing the switch was not identified.80 By analogy to the other 1,3-intrastrand crosslinked adducts, it is probably the 5'-deoxyguanosine. A schematic representation of the structure of the platinated trinucleotide in trans $-\left[\mathrm{Pt}\left(\mathrm{NH}_{3}\right)_{2}\{\mathrm{~d}(\mathrm{ApGpGpCpCpT})\}\right]$, drawn to reflect what presently is known about the backbone and deoxyribose conformations, is shown in Fig. 8. The large, 23-membered ring containing the platinum atom and part of the destacked deoxyguanosine nucleoside in Fig. 8 may be contrasted with the smaller, 17-membered, cis- $\left\{\mathrm{Pt}\left(\mathrm{NH}_{3}\right)_{2}\right\}^{2+}$-containing ring in $\mathrm{Fig} \cdot 7 . \mathrm{Ex}-$ actly how the trans-DDP adducts distort double-stranded DNA structure is important to learn, for geometric differences between the cis- and trans-DDP crosslinks may correlate with their different biological activities.

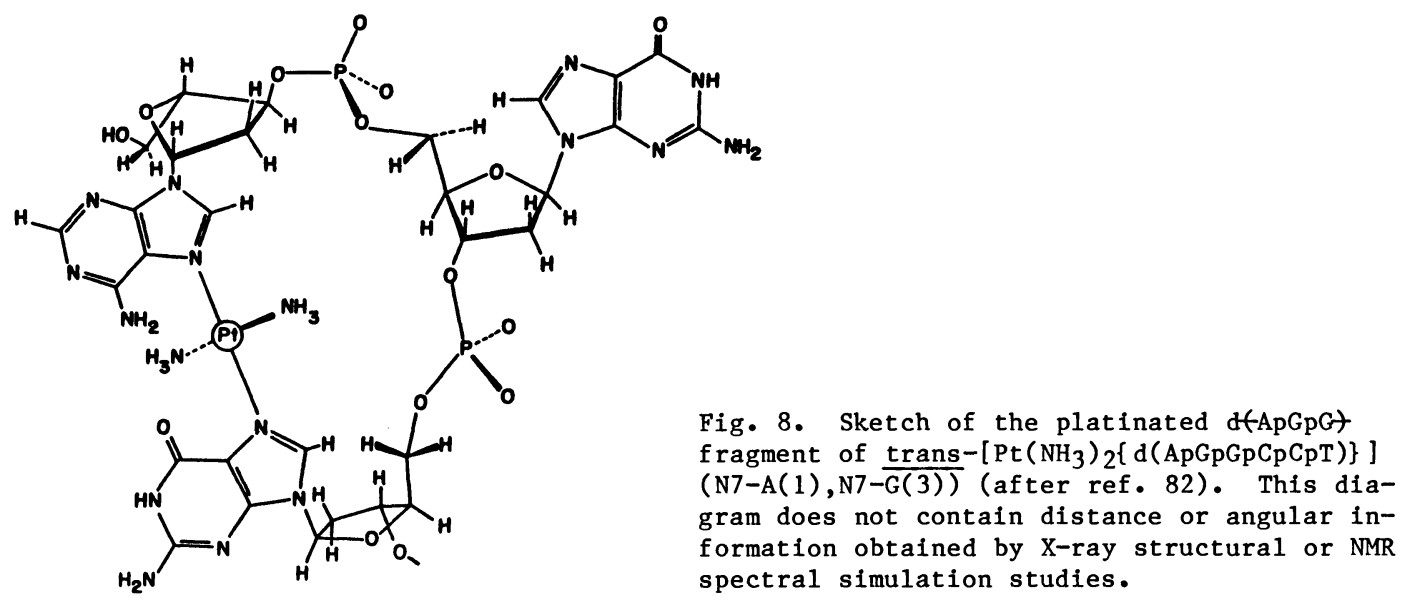


As with the cis isomer, binding of trans-DDP to DNA unwinds and shortens the double helix,19,34 although reports differ about their relative abilities to do so.34,83 Both phenomena depend critically upon the ratio of bound platinum per nucleotide. Recent experiments with antibodies provide some fresh insights into DNA structural distortions induced by trans-DDP adducts. Anti-nucleoside antibodies recognize trans-DDP-modified DNA significantly better than cis-DDPmodified DNA at comparably low D/N ratios (< 0.02).46 Moreover, a monoclonal antibody has now been developed for trans-DDP-modified calf thymus DNA, and the only double-stranded, synthetic DNA polymer to which this antibody binds was shown to be trans $-\left\{\mathrm{Pt}_{\mathrm{N}}\left(\mathrm{NH}_{3}\right)_{2}\right\}{ }^{2+}-\mathrm{platinated}$ poly$[\mathrm{d}(\mathrm{GT})] \cdot \operatorname{poly}[\mathrm{d}(\mathrm{CA})] .^{45}$ Taken together, these results are consistent with the occurrence of trans $-\left\{\mathrm{Pt}\left(\mathrm{NH}_{3}\right)_{2}\right\}^{2+}$-induced 1,3-intrastrand crosslinks of the kind shown in Fig. 8 in duplex DNA platinated with trans-DDP, accompanied by considerable base pair disruption and helix destacking. NMR and X-ray structural investigations of double helical DNA containing trans-DDP adducts should further clarify the situation, and reveal any additional binding modes.

\section{Monofunctional Pt-DNA adducts}

Although both cis- and trans-DDP form monofunctional adducts on DNA, 38-40,78,79 where the $\left\{\mathrm{Pt}\left(\mathrm{NH}_{3}\right)_{2}\right\}^{2+}$ unit is coordinated to only one donor atom from the polynucleotide, a recent study reveals the number and lifetime of such adducts to be much greater for platination by the trans isomer. ${ }^{84}$ This work suggests that the second link to a monofunctional trans-DDP-DNA adduct is more likely to occur to a ligand from some source other than DNA, compared with similar cisDDP-DNA monofunctional adducts.

\section{BIOLOGICAL CONSEQUENCES OF PLATINUM-DNA ADDUCTS}

The foregoing discussion highlights differences between the most prevalent, intrastrand crosslinks formed by cis- versus trans-DDP on DNA. How might this information be used to understand the different cytotoxic effects of the two isomers? It is impossible within the scope of the present article to discuss fully all ramifications of this question, for it involves at least the relative abilities of Pt-DNA adducts to inhibit replication, be repaired, cause mutations, and possibly induce drug resistance. Moreover, while it has been possible to reach a consensus on the regioselectivity and stereospecificity of platinum-DNA adducts for both cis- and trans-DDP, such has not yet been the case for questions related to the differential inhibition of replication, mutation induction, and repair of specific adducts. Different protocols used by investigators in different laboratories contribute in part to this situation, since covalent reactions of platinum ammine chloride complexes are sensitive to incubation times and to components in media used to dissolve them and nurture cells. One attractive approach to sorting out these problems is described in the following section.

\section{SITE-SPECIFICALLY PLATINATED DNA}

The reaction of platinum complexes with DNA in vitro or in vivo leads to a variety of products in which platinum atoms are located at numerous sites in the genome. It is inherently difficult to discern, using this globally platinated DNA, the consequences of position and structure of any one adduct on DNA function. To address this problem, a new probe of the biological activity of platinum anticancer drugs has been developed in which the cis $-\left\{\mathrm{Pt}\left(\mathrm{NH}_{3}\right)_{2}\right\}{ }^{2+}$ fragment is located in a unique, programmable site on the genome.85,86 As shown in Fig. 9, this material is prepared by ligating a chemically synthesized oligonucleotide containing the desired platinum adduct into a gapped duplex obtained by recombinant DNA techniques. The resulting site-specifically modified genome can then be used for various repair, mutagenesis, and survival studies both in vitro and, following its introduction into cells by transformation, in vivo.

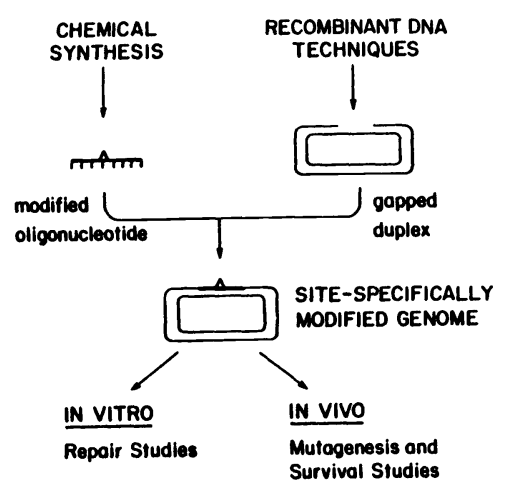

Fig. 9. General scheme for building sitespecific DNA adducts into a viral genome. The intrastrand crosslink is indicated by a small triangle (from ref. 86). 
The first adduct, built into DNA from bacteriophage M13, is shown in the box below. 85 The

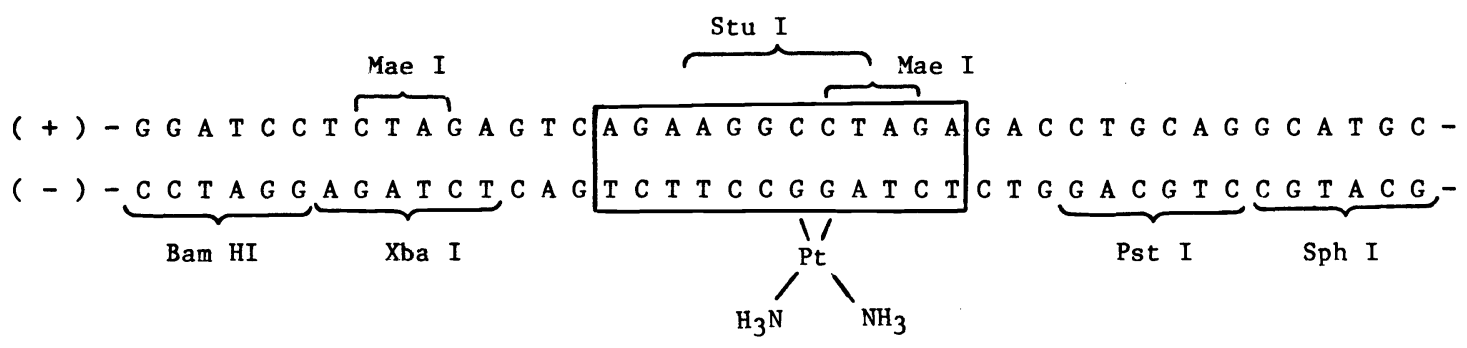

presence of platinum inhibits cleavage of the modified DNA by restriction endonucleases Stu I and Mae I (in the box), but not by Bam HI, Xba I, Pst I, Sph I or Mae I (out of the box). Thus, structural distortions induced in DNA by the cis- $\left[\mathrm{Pt}\left(\mathrm{NH}_{3}\right){ }_{2}\{\mathrm{~d}(\mathrm{GpG})\}\right]$ intrastrand crosslink are fairly localized, to within one helical turn from the site of platination. Addition of cyanide to the modified M-13 DNA removes platinum as $\left[\mathrm{Pt}(\mathrm{CN})_{4}\right]^{2-}$, and restores sensitivity to cleavage by restriction enzymes.85 The construction of other such site specifically modified genomes, with different sequences and platinum complexes, and examination of their biological properties in vivo, should enable firm conclusions to be drawn about the relevance of different adducts to the mechanism of action of platinum anticancer drugs.

\section{CONCLUDING REMARKS}

The major DNA adducts formed between platinum anticancer drugs and their inactive analogs have been mapped and structurally characterized, combining modern DNA sequencing and synthetic technologies with structurally powerful methods of NMR spectroscopy and X-ray diffraction. This goal could not have been achieved in 1969, the year in which the anticancer activity of cis-DDP was reported, for many of the methodologies employed were simply not available at that time. How any or all of these platinum-DNA complexes leads ultimately to cytotoxicity and anticancer activity are subjects for future studies. Knowledge of these in vivo processes should, ultimately, lead to the more rational design of platinum and other metal based anticancer drugs.

\section{Acknowledgment}

This work was supported by U.S. Public Health Service Grant CA-34992 from the National Cancer Institute. I am indebted to many graduate students, postdoctoral associates, and faculty colleagues and collaborators for stimulating discussions and experimental skills reflected in the work and ideas contained in this article. The names of most of these individuals appear in references to published work from our laboratory cited below.

\section{REFERENCES AND NOTES}

1. B. Rosenberg, L. Van Camp, J.E. Trosko, and V.H. Mansour, Nature 222, 385 (1969).

2. P.J. Loehrer and L.H. Einhorn, Ann. Intern. Med. $100,704 \overline{(1984)}$.

3. C.F.J. Bernard, M.J. Cleare, and P.C. Hydes, Chem. Brit. 22, 1001 (1986).

4. J.H. Burchenal, K. Kalaher, K. Dew, L. Lokys, and G. Gale, Biochimie 60, 961 (1978).

5. J.J. Roberts and A.J. Thompson, Progr. Nucl. Acids Res. Mol. Biol. 22, 71 (1979).

6. R.B. Ciccarelli, M.J. Solomon, A. Varshavsky, and S.J. Lippard, Biochemistry 24, 7533 (1985).

7. J.J. Roberts and J.M. Pascoe, Nature 235, 282 (1972).

8. L.A. Zwelling, K.W. Kohn, W.E. Ross, R.A.G. Ewig, and T. Anderson, Cancer Res. 38,1762 (1978).

9. P.J. Stone, A.D. Kelman, and F.M. Sinex, Nature 251, 736 (1974).

10. G.L. Cohen, J.A. Ledner, W.R. Bauer, H.M. Ushay, C. Caravana, and S.J. Lippard, J. Am. Chem. Soc. 102,2487 (1980).

11. T.D. Tullius and S.J. Lippard, J. Am. Chem. Soc. 103, 4620 (1981).

12. B. Royer-Pokora, L.K. Gordon, and W.A. Haseltine, Nucleic Acids Res. 9, 4595 (1981).

13. A.L. Pinto and S.J. Lippard, Biochim. Biophys. Acta 780, 167 (1985).

14. J.K. Barton and S.J. Lippard in T.G. Spiro, Ed., Metal Ions in Biology 1, p. 31, Wiley, New York (1980).

15. W. Saenger, Principles of Nucleic Acid Structure, Springer, New York (1984).

16. J.K. Barton, Science 233, 727 (1986).

17. D. Mendel and P.B. Dervan, Proc. Nat1. Acad. Sci., USA 84, 910 (1987).

18. S.J. Lippard and J.D. Hoeschele, Proc. Natl. Acad. Sci., USA 76, 6091 (1979).

19. J.-P. Macquet and J.-L. Butour, Biochimie 60, 901 (1978).

20. B.E. Bowler, L.S. Hollis, and S.J. Lippard, J. Am. Chem. Soc. 106, 6102 (1984). 
21. M.E. Howe-Grant and S.J. Lippard, Met. Ions Biol. Syst. 11,63 (1980).

22. M.A. Tucker, C.B. Colvin, D.S. Martin, Jr., Inorg. Chem. $\frac{3}{3}, 1373$ (1964).

23. M.C. Lim and R.B. Martin, J. Inorg. Nuc1. Chem. 38, 1911 (1976).

24. K. Uchida, Y. Tanaka, T. Nishimura, Y. Hashimoto, T. Watanabe, and I. Haroda, Biochem. Biophys. Res. Commun. 138, 631 (1986).

25. A. Kraker, J. Schmidt, S. Krezoski, and D.H. Petering, Biochem. Biophys. Res. Commun. 130, 785 (1985).

26. S.K. Maudlin, F.A. Richard, M. Plescia, S.D. Wyrick, A. Sancar, and S.G. Chaney, Analyt. Biochem. 157, 129 (1986).

27. P.A. Andrews, M.P. Murphy, and S.B. Howe11, Cancer Res. 45, 6250 (1985).

28. D.L. Bodenner, P.C. Dedon, P.C. Keng, J.C. Katz, and R.F. Borch, Cancer Res. 46, 2751 (1986).

29. S.B. Howe11, C.E. Pfeifle, W.E. Wung, and R.A. 01shen, Cancer Res. 43, 1426 (1983).

30. J.J. Roberts and F. Friedlos, Cancer Res. 47, 31 (1987).

31. B. Drewinko, M.A. Dipasquale, L.Y. Yeng, B. Barlogie, and J.M. Trujillo, Chem.-Biol. Interactions 55, 1 (1985).

32. W.I. Sundquist, K.J. Ahmed, L.S. Hollis, and S.J. Lippard, Inorg. Chem. (1987), in press.

33. S.J.S. Kerrison and P.J. Sadler, J. Chem. Soc. Chem. Commun. 861 (1977).

34. G.L. Cohen, W.R. Bauer, J.K. Barton, and S.J. Lippard, Science 203, 1014 (1979).

35. C.M. Merkel and S.J. Lippard, Cold Spring Harbor Symp. Quant. Biol. 47, 355 (1983).

36. A.L. Pinto and S.J. Lippard, Proc. Nat1. Acad. Sc1., USA 82, 4616 (1985).

37. B.E. Bowler and S.J. Lippard, Biochemistry 25, 3031(1986).

38. A.M.J. Fichtinger-Schepman, P.H.M. Lohman, and J. Reedijk, Nucl. Acids Res. 10, 5345 (1982).

39. A.M.J. Fichtinger-Schepman, J.L. van der Veer, J.H.J. den Hartog, P.H.M. Lohman, and J. Reedijk, Biochemistry 24, 707 (1985).

40. A. Eastman, Biochemistry 25, 3912 (1986).

41. A.C.M. Plooy, A.M.J. Fichtinger-Schepman, H.H. Schutte, M. van Dijk, and P.H.M. Lohman, Carcinogenesis 6 , 561 (1985).

42. B. Malfoy, B. Hartmann, J.-P. Macquet, and M. Leng, Cancer Res. 41, 4127 (1981).

43. M.C. Poirier, S.J. Lippard, L.A. Zwelling, H.M. Ushay, D. Kerrigan, G.C. Thill, R.M. Santella, D. Grunberger, and S.H. Yuspa, Proc. Natl. Acad. Sci., USA 79, 6443 (1982).

44. S.J. Lippard, H.M. Ushay, C.M. Merke1, and M.C. Poirier, Biochemistry 22, 5165 (1983).

45. W.I. Sundquist, S.J. Lippard, and B.D. Stollar, submitted for publication.

46. W.I. Sundquist, S.J. Lippard, and B.D. Stollar, Biochemistry 25, 1520 (1986).

47. T.D. Tullius and S.J. Lippard, Proc. Natl. Acad. Sci., USA 79, 3489 (1982).

48. N. Assa-Munt, W. Leupin, W.A. Denny, and D. Kearns, Biochemistry 24, 1449 (1985).

49. J.-C. Chottard, J.-P. Girault, G. Chottard, J.-Y. Lallemand, and D. Mansuy, J. Am. Chem. Soc. $102,5565(1980)$.

50. J.-P. Girault, G. Chottard, J.-Y. Lallemand, and J.-C. Chottard, Biochemistry 21,1352 (1982).

51. J.H.J. den Hartog, C. Altona, J.-C. Chottard, J.-P. Girault, J.-Y. Lallemand, F.A.A.M. de Leeuw, A.J.M. Marcelis, and J. Reedijk, Nucleic Acids Res. 10, 4715 (1982).

52. B. van Hemelryck, J.-P. Girault, G. Chottard, P. Valadon, A. Laoui, and J.-C. Chottard, Inorg. Chem. 26 (1987), in press.

53. S.E. Sherman, D. Gibson, A.H.-J. Wang, and S.J. Lippard, Science 230,412 (1985).

54. J. Brouwer, P. van de Putte, A.M.J. Fichtinger-Schepman, and J. Reedijk, Proc. Nat1. Acad. Sci., USA 78, 7010 (1981).

55. D. Burnouf, M. Daune, and R.P.P. Fuchs, Proc. Nat1. Acad. Sci., USA (1987), in press.

56. A.T.M. Marcelis, J.H.J. den Hartog, and J. Reedijk, J. Am. Chem. Soc. 104,2664 (1982).

57. J.H.J. den Hartog, C. Altona, H. van den Elst, G.A. van der Marel, L.J. Rinkel, G. WilleHazeleger, and J. Reedijk, Eur. J. Biochem. 134, 485 (1983).

58. J.L. van der Veer, H. van den Elst, J.H.J. den Hartog, A.M.J. Fichtinger-Schepman, and J. Reedijk, Inorg. Chem. 25, 4657 (1986).

59. J.L. van der Veer, G.J. Ligtvoet, H. van den Elst, and J. Reedijk, J. Am. Chem. Soc. 108, 3860 (1986).

60. A.T.M. Marcelis, J.H.J. den Hartog, G.A. van der Marel, G. Wille, and J. Reedijk, Eur. J. Biochem. 135, 343 (1983).

61. J.H.J. den Hartog, C. Altona, H. van den Elst, G.A. van der Marel, and J. Reedijk, Inorg. Chem. 24, 986 (1985).

62. J.H.J. den Hartog, C. Altona, G. van der Mare1, and J. Reedijk, Eur. J. Biochem. 147, 371 (1985).

63. G. Admiraal, J.L. van der Veer, R.A.G. de Graef, J.H.J. den Hartog, and J. Reedijk, J. Am. Chem. Soc. 109, 592 (1987).

64. A.T.M. Marcelis, G.W. Canters, and J. Reedijk, Recl. Trav. Chim. Pays-Bas 100, 391 (1981).

65. J.-P. Girault, J.-C. Chottard, J.-M. Neumann, S. Tran-Dinh, T. Huynh-Dinh, and J. Igolen Nouv. J. Chim. 8, 7 (1984).

66. J.-M. Neumann, S. Tran-Dinh, J.-P. Girault, J.-C. Chottard, T. Huynh-Dinh, and J. Igolen, Eur. J. Biochem. 141, 465 (1984).

67. J.P. Caradonna, S.J. Lippard, M.J. Gait, and M. Singh, J. Am. Chem. Soc. 104, 5793 (1982).

68. J.-P. Girault, J.-C. Chottard, E.R. Guittet, J.-Y. Lallemand, T. Huynh-Dinh, and J. Igolen, Biochem. Biophys. Res. Commun. 130,758 (1986). 
69. J.H.J. den Hartog, C. Altona, J.H. van Boom, G.A. van der Marel, C.A.G. Haasnoot, and J. Reedijk, J. Am. Chem. Soc. 106, 1528 (1984).

70. B. van Hemelryck, E. Guittet, G. Chottard, J.-P. Girault, T. Huynh-Dinh, J.-Y. La1lemand, J. Igolen, and J.-C. Chottard, J. Am. Chem. Soc. 106, 3037 (1984).

71. B. van Hemelryck, E. Guittet, G. Chottard, J.-P. Girault, F. Herman, T. Huynh-Dinh, J.-Y. Lallemand, J. Igolen, and J.-C. Chottard, Biochem. Biophys. Res. Commun. 130, 758 (1986).

72. J. Kozelka, G.A. Petsko, G.J. Quigley, and S.J. Lippard, Inorg. Chem. 25, 1075 (1986).

73. J. Kozelka, S. Archer, G.A. Petsko, S.J. Lippard, and G.J. Quigley, Biopolymers, in press.

74. J. Kozelka, G.A. Petsko, G.J. Quigley, and S.J. Lippard, J. Am. Chem. Soc. 107, 4079 (1985).

75. R.M. Wing, P. Pjura, H.R. Drew, and R.E. Dickerson, The EMBO J. $\frac{3}{1}, 1201$ (1984).

76. J.R. Rubin, M. Sabat, and M. Sundaralingam, Nucleic Acids Res. $1 \frac{11}{1}, 6571$ (1983).

77. J.C. Dewan, J. Am. Chem. Soc. 106, 7239 (1984).

78. L.A. Zwelling, T. Anderson, and K.W. Kohn, Cancer Res. 39, 365 (1979).

79. L.A. Zwelling, M.0. Bradley, N.A. Sharkey, T. Anderson, and K.W. Kohn, Mut. Res. 67,271 (1979).

80. J.L. van der Veer, G.J. Ligtvoet, H. van den E1st, and J. Reedijk, J. Am. Chem. Soc. 108, 3860 (1986).

81. D. Gibson and S.J. Lippard, Inorg. Chem., in press.

82. C.A. Lepre, K.G. Strothkamp, and S.J. Lippard, submitted for publication.

83. W.M. Scove11 and V.J. Capponi, Biochem. Biophys. Res. Commun. 124, 367 (1984).

84. J.-L. Butour and N.P. Johnson, Biochemistry 25, 4534 (1986).

85. A.L. Pinto, L.J. Naser, J.M. Essigmann, and S.J. Lippard, J. Am. Chem. Soc. 108, 7405 (1986).

86. L.J. Naser, A.L. Pinto, S.J. Lippard, and J.M. Essigmann in E. Friedberg and P. Hanawalt, Eds., DNA Repair: A Laboratory Manual of Research Procedures, Vo1. 3, Dekker, New York, in press. 